\title{
AÜSBD
}

Anadolu Üniversitesi Sosyal Bilimler Dergisi

Anadolu University Journal of Social Sciences

\section{İş-Yaşam Dengesinin Yaşam Tatminini Yordamasında Çalışılan Sektörün Düzenleyici Etkisi ${ }^{1}$}

\author{
Mustafa BEKMEZCi ${ }^{2}$ - İbrahim Sani MERT ${ }^{3}$ - Mohammad ABUBAKAR ${ }^{4}$
}

Başvuru Tarihi: 27.06.2019

Kabul Tarihi: 25.12 .2020

Makale Türü: Araştırma Makalesi

\section{Öz}

İs-yaşam dengesi ve yaşam tatmini arasındaki ilişkiyi araştıran çalışmalar ilgili yazında artarak devam etmektedir. Özellikle çift kariyerli aile yapısının giderek arttığı günümüzde, iş-yaşam dengesi ve bu dengenin bireylerin yaşam tatminini nasıl etkilediği, bu etki üzerinde rol oynayan faktörlerin neler olduğunun bilinmesi önem kazanmıştır. Bu kapsamda 622 kişi üzerinde yapılan bu araştırmada, iş-yaşam ve yaşam-iş çatışmasının kamu ve özel sektör çalışanları üzerindeki yaşam tatminini ne ölçüde etkilediği araştırılmıştır. Yapısal eşitlik modelinin (SEM) kullanıldiğı çalışmada, iş-yaşam çatışmasının (işin kişisel yaşama etkisi) yaşam tatminini azalttı̆̆l, çalışılan sektörün (kamu ve özel) iş-yaşam dengesi ve yaşam tatmini arasındaki ilişkide düzenleyici bir etkiye sahip olduğu tespit edilmiştir. Kamu sektöründe çalışanlarda iş-yaşam çatışmasının (işin kişisel yaşama etkisi) yaşam tatminini azaltması daha fazladır. Diğer yandan, yaşam-iş çatışması (kişisel yaşamın işe etkisi) yaşam tatminini etkilememektedir.

Anahtar Kelimeler: İş-Yaşam Dengesi, Yaşam Tatmini, Düzenleyici Etki

Atıf: Bekmezci, M., Mert, İ. S. ve Abubakar, M. (2021). İş-yaşam dengesinin yaşam tatminini yordamasında çalışlan sektörün düzenleyici etkisi. Anadolu Üniversitesi Sosyal Bilimler Dergisi, 21(1), 1-22.

\footnotetext{
${ }^{1}$ Bu çalışma 2019 yılı içerisinde dergiye yayın başvurusunda bulunulmuş makale olduğundan geriye dönük etik kurul izni gerekmemektedir

${ }^{2}$ Toros Üniversitesi İISBF İşletme Bölümü, mustafa.bekmezci@toros.edu.tr, ORCID: 0000-0002-1206-690X

${ }^{3}$ Antalya Bilim Üniversitesi, İ̇SB Fakültesi İşletme Bölümü, ibrahim.mert@antalya.edu.tr, ORCID: 0000-0002-2850-18650000-0002-2068-2841

${ }^{4}$ Antalya Bilim Üniversitesi, İISB Fakültesi İşletme Bölümü, muhammad.abubakar@antalya.edu.tr, ORCID: 0000-0002-1163-0185
} 


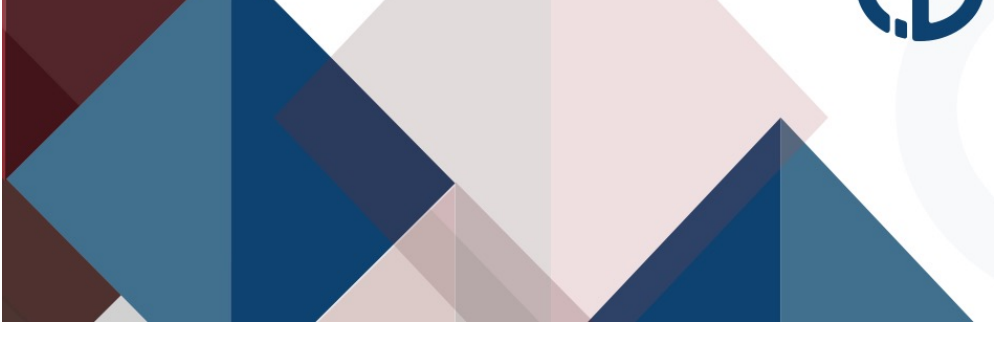

\title{
The Moderating Role of the Working Sector in Evaluating Life Satisfaction on Work-Life Balance
}

\author{
Mustafa BEKMEZCi ${ }^{5}$ - Ibrahim Sani MERT ${ }^{6}$ - Mohammad ABUBAKAR ${ }^{7}$
}

\begin{abstract}
Studies on the relationship between work-life balance and life satisfaction continue to increase in the relevant literature. In today's world where double career family structures are gradually increasing, the importance of work-life balance and how this balance affects the life satisfaction of individuals and the factors that play a role in this effect have gained importance. In this study, the effect of work-life and life-work conflict on the life satisfaction of public and private sector employees was investigated. 622 people answered the survey. Structural equation modeling (SEM) was used in this study. It has been determined that the work-life conflict (the effect of the work on personal life) reduces life satisfaction and the sector (public and private) has a moderating role on the relationship between work-life balance and life satisfaction. In the public sector, the work-life conflict (the impact of the work on personal life) is more likely to reduce life satisfaction. On the other hand, the life-work conflict (the effect of personal life on work) does not affect life satisfaction.
\end{abstract}

Keywords: Work-Life Balance, Life Satisfaction, Moderating Role

\footnotetext{
${ }^{5}$ Toros University Faculty of Economics Administrative and Social Sciences, mustafa.bekmezci@toros.edu.tr, ORCID: 0000-0002-1206-690X

${ }^{6}$ Antalya Bilim University School of Business and Social Sciences, Department of Business Administration, ibrahim.mert@antalya.edu.tr, ORCID: 0000-0002-2850-18650000-0002-2068-2841

7 Antalya Bilim University School of Business and Social Sciences, Department of Business Administration, muhammad.abubakar@antalya.edu.tr, ORCID: 0000-0002-1163-0185
} 


\section{Giriş}

Günümüzde her sektörde yaşanan rekabet, çalışanlardan daha yüksek performans beklemeyi örgütler açısından zorunluluk haline getirmiştir. Diğer bir ifade ile yoğun rekabet içinde olan organizasyonların varlıklarını sürdürebilmesi, çalışanlarından beklediği yüksek performansa bağlıdır.

Diğer yandan, günümüzde farkındalık seviyesi yüksek, geçmişle kıyaslandığında yaşamdan daha çok tatmin olma arayışında olan bilinçli bir çalışan kitlesinin mevcudiyeti söz konusudur. Gerek kamuda gerek özel sektörde başarılı olmanın üstün performans göstermekle ilişkilendirilmesi, iş yaşamında beklentileri artırmıştır. Ancak insanların yaşamdan tatmin olma isteği de iş yaşamı dışındaki beklentileri artırmıştır. Böylece bireylerin sadece iş yaşamından değil, özel yaşamından da beklentileri artmıştır. Bu durum, iş-yaşam dengesini, hangi sektörde olursa olsun, mavi ve beyaz yakalı işgörenler için önemli hale getirmiştir.

Ayrıca, iş dünyası ve aile yaşamının yapısı son yarım asırda önemli ölçüde değişmiştir. Bunun en başta gelen nedenlerinden bir tanesi, iş dünyasındaki kadın çalışanların sayısında görülen artıştır (Önder, 2013). Bu durum, "iki kariyerli aile" olarak ifade edilen ve eşlerin her ikisinin de çalışmasını kapsayan araştırmaların da iş-yaşam dengesini ön plana çıkardığı görülmektedir (Mert ve Bekmezci, 2016).

İş-yaşam dengesinin bu çalışma kapsamında da ele alındığı gibi, iki boyutu vardır. İş-yaşam çatışması, diğer bir ifadeyle işin kişisel yaşama etkisi ve diğer taraftan yaşam-iş çatışması diğer bir ifadeyle özel yaşamın işe etkisi şeklindedir. Bu iki boyutta ele alınan iş-yaşam çatışmasının, iş tatminini de içine alan yaşam tatminini nasıl etkilediği önem arz etmektedir. Çünkü yaşam tatmini, bundan çok daha fazlasını içermektedir. Ancak yaşamda önemli bir pay sahibi olan iş yaşamının özel yaşamla olan etkileşimini ifade eden iş-yaşam dengesinin genel olarak yaşam tatmini nasıl etkilediğinin bilinmesi önemlidir. Bu kapsamda değerlendirildiğinde, yaşam tatmini üzerinde etkisi olan en önemli faktörlerden biri iş-yaşam dengesidir. Nitekim konuyla ilgili yapılan araştırmalar, iş-yaşam dengesi ve yaşam tatmini arasındaki ilişkinin varlığını ve önemini ön plana çıkarmakta ve bu ilişkinin daha kapsamlı incelenmesi gerekliliğini vurgulamaktadır (Örneğin, Karatepe ve Bekteshi, 2008; Adams vd., 1996; Greenhaus ve Powell, 2006; Marks ve MacDermid, 1996; Barnett ve Hyde, 2001).

Diğer yandan, iş-yaşam dengesini oluşturan işin kişisel yaşama etkisi ve kişisel yaşamın işe etkisi boyutlarının yaşam tatmini ile olan ilişkisinde çalışllan sektörün nasıl bir etkiye sahip olduğu araştırılması gereken bir konu olarak karşımıza çıkmaktadır. Bu kapsamda, farklı sektörlerde yapılan araştırmalara rastlanmaktadır. Örneğin, Umer ve Zia-ur-Rehman (2013) tarafından eğitim sektöründe çalışanların iş-yaşam dengeleri ile yaşam tatminleri arasında, Kumari (2012) tarafından yapılan bir çalışmada ise, kamu bankalarında çalışan işgörenlerin iş-yaşam dengesi ve iş doyumları arasında ilişki olduğu belirlenmiştir. Benzer şekillde Haar, Russo, Suñe ve Ollier-Malaterre (2014) tarafından daha farklı sektörlerde yapılan çalışmada da iş-yaşam dengesi ve yaşam tatmini arasında ilişki bulunmuştur. Çalışılan sektör denildiğinde en genel anlamda yapılan ayrım, kamu ve özel sektör ayrımıdır. Bireylerin çalışma hayatına atılırken belki de ilk karar vereceği seçenek veya konu, kariyerlerinin özel sektör veya kamu sektöründe olup olmayacağını belirlemektir. Bu kapsamda, iş ve yaşam arasında denge kurmanın yaşam tatminini yordama derecesinde, işgörenlerin çalıştığı sektörde, diğer bir ifadeyle bireylerin kamu veya özel sektörde görev yapmasının herhangi bir etkiye sahip olup olmadığının bilinmesi, yaşam tatmininin ve iş ilişkisinin anlaşışması yordanması açısından önemlidir. Yaşam tatmini, bir insanın sahip olabileceği en önemli tatmindir (Pavot ve Diener, 2008). Yaşam tatmini yüksek bireyler, bunu performanslarına yansıtacaklar, böylece daha verimli ve etkili olabilecektir (Akter vd., 2019).

Yapılan bu değerlendirmeler kapsamında, bu çalışmada araştırma soruları şu şekilde belirlenmiştir:

- İşin kişisel yaşama etkisi, yaşam tatminini etkilemekte midir?

- Kişisel yaşamın işe etkisi, yaşam tatminini etkilemekte midir? 
- İş yaşam dengesinin yaşam tatmini üzerindeki etkisi olarak özetleyebileceğimiz bu iki durumda, çalışılan sektörün yani kamu veya özel sektörde olup olmamanın, düzenleyici etkisi var mıdır?

Araştırmanın bundan sonraki bölümünde iş-yaşam dengesi ve yaşam tatminine ilişkin kısa bir literatür incelemesine yer verilmiştir. Müteakiben, araştırma yöntemine ilişkin metodoloji bölümü ve bulgulara değinilmiştir. Sonuç, kısmında ise araştırma bulguları bundan sonra yapılacak benzer araştırmalara da ışık tutacak şekilde değerlendirilmiştir.

\section{Kavramsal Çerçeve İş-yaşam Dengesi}

Günümüzde çalışma hayatı, geçmişe nazaran oldukça değişmiştir. Bu değişiklik insanların, çocuklarına ve yaşlı ebeveynlerine bakmak, hobileri ve sosyal faaliyetleri için zaman ayırmak istemesinden kaynaklanmaktadır (Webber vd., 2010; Narayanan ve Narayanan, 2012). Ancak teknolojideki gelişmeler iş ve yaşam arasındaki sınırları ortadan kaldırmıştır (Nam, 2014). Sınırların ortadan kalkması insanların zaman ve mekân fark etmeksizin sürekli işiyle meşgul olmasına, dolayısıyla daha yoğun çalışmasına neden olmuştur. Ayrıca iş dünyasında kadınların sayısı artmıştır, eşlerin ikisi de çalışmaktadır. Örgütlerin küçülmeyi bir strateji olarak görmesinin ve uygulamasının bir neticesi olarak, işgörenlerin örgüte bağlllığı da azalmıştır (Demir, 2010). Ancak çalıştığı örgüte bağlı, kendisini işine adayan işgörenlere ihtiyaç her geçen gün artmaktadır (Friedman vd., 1998). İnsanlara, kendilerinin değerli olduğunu hissettirmenin, finansal başarıyı artırdığı da gözlemlenmiştir (Narayanan ve Narayanan, 2012). Bunların yanında günümüz işyerinde farklı özelliklere sahip kuşaklar birlikte çalışmaktadır. X ve Y kuşakları kendisine ve ailesine daha fazla zaman ayırmak istemektedir. Bu istek, esnek çalışma, evde çalışma, mobil çalışma gibi alternatif çalışma şartlarını kendilerine sunma konusunda şirketler üzerinde bir baskı oluşturmaktadır (Klun, 2008). Bu tür düşünce, talep ve yaklaşımlar iş-yaşam dengesi konusunun daha ayrıntılı araştırılmasını gerektirmiş, bu konu ile ilgili yapılan araştırmalara ilgiyi artırmıştır.

İş-yaşam dengesi, "işyerindeki uygulamalarla, işgörenin kendi ailesi (yaşamı) ile iş hayatının talepleri arasında işgörenlerin ihtiyaçlarını giderecek şekilde denge sağlanmasıdır” (Jyothi ve Jyothi, 2012, s. 37). İş-yaşam dengesi, aslında kişinin işi ve ailesi arasındaki dengeden daha fazlasını ifade etmektedir. İş-yaşam dengesini, kişinin işindeki ve iş dışındaki tüm faaliyetleri arasında bir denge kurması olarak değerlendirmek gerekir (Shankar ve Bhatnagar, 2010). Bu kapsamda, iş-yaşam dengesi, kişinin işine, kendisine ve ailesine yönelik amaçlarını ve taleplerini dengelemesidir. İş-yaşam dengesi konusundaki ilk araştırmalarda, işgörenlerin kendi ailesine karşı yerine getirmesi gereken sorumlulukları olarak değerlendirilmiş (Webber vd., 2010); şirketin kreş imkânı sağlaması, kreş masraflarını karşılaması, bakıma muhtaç yaşlılara bakım imkânı sunması, ihtiyaç halinde ücretli veya ücretsiz izin vermesi, esnek çalışma programlarının uygulanması gibi konular uygulamaya konmuştur (Perry ve Blum, 2000). Ancak, bu uygulamaların iş-yaşam dengesine çok fazla katkı sağlamadığ1 görülmüştür. Çünkü bu tür programlar, genellikle bir bütün olarak ele alınmamış, şirket kültürüne nüfuz etmemiş, yöneticilerin davranışında bir değişiklik yaratmamıştır (Batt ve Volcour, 2003). Yöneticilerin destek vermediği bir uygulamanın başarılı olması mümkün değildir. Bu kapsamda, iş-yaşam dengesi ile ilgili yapılan programlarda ve uygulamalarda yöneticilerin desteği büyük bir öneme sahiptir (Ueda, 2012). İş-yaşam dengesi ile ilgili yapılan programların başarılı olmamasının nedenlerinden biri de bu programların sadece çocuklu ailelere uygulanmasından kaynaklanmıştır. Bekar veya çocuk sahibi olmayan işgörenler bu uygulamaları adil bulmamış (Young, 1999); eğitim, gönüllü çalışma, spor, hobi eğlence gibi kişisel ihtiyaçların da bu kapsamda değerlendirilmesi gerektiğini ifade etmiştir. Ayrıca bu kişilerin çocuklu ailelere göre duygusal anlamda aile desteğinden mahrum olması, kendilerini dışlanmış gibi hissetmesine neden olmuştur (Casper vd., 2007). Netice itibariyle iş, insanın iş dışındaki önceliklerini gerçekleştirmek için bir araçtır (Friedman vd., 1998). 
Dolayısıyla, iş-yaşam dengesi, sadece evli ve çocuklu aileleri değil, çalışan herkesi ilgilendiren ve bu şekilde ele alınması gereken daha geniş bir kavramdır (Shankar ve Bhatnagar, 2010).

\section{İş-Yaşam Dengesi ile ilgili Kuramlar}

İş ve yaşam ile ilgili beş temel kuram geliştirilmiştir (Leiter ve Durup, 1996; Zedeck ve Mosier, 1990): Bölünme (segmentation) modeli, iş ve iş dışı faaliyetlerin hayatın farklı iki alanı olduğunu ve bu ikisinin birbiri üzerinde etkisi olmadığını; taşma (spillover) modeli iş ve iş dışı faaliyetlerin birbirini benzer şekilde olumlu veya olumsuz biçimde etkileyebileceğini, telafi (compensation) modeli de iş veya yaşamın herhangi birinde yaşanan bir eksikliğin, işgörenin tatmin olma ihtiyacından dolayı bu eksikliği diğer alanda karşılayabileceğini varsayar. Örneğin rutin bir işin işgörende yaratmış olduğu tatminsizlik duygusu, işgören tarafından iş dışındaki diğer faaliyetler ile telafi edilebilir. Aracı olma (instrumental) modeli iş veya yaşam alanındaki bir faaliyetin hem iş hem de yaşam alanındaki başarıyı kolaylaştırdığını kabul eder. Çatışma (conflict) modelinin varsayımı ise şöyledir: İş ve yaşam alanının her ikisinin farklı talepleri, işgörenin bazı katı kararlar almasını gerektirir. Bu durum da işgörenin üzerinde aşırı bir yük oluşturur ve işgörenin işi ve yaşamı arasında bazı çatışmalara neden olabilir.

Çatışma modeli alan yazında üzerinde en çok durulan modeldir. Bu modelde ailenin işi, işin de aileyi etkileyebileceği ifade edilerek, konu çift yönlü olarak ele alınmıştır (Frone vd., 1992). Diğer bir ifade ile işyerinde yaşanan olumsuzluklar aileyi veya yaşamı, ailede yaşanan olumsuzluklar da işyerindeki faaliyetleri etkilemektedir. Her ne kadar iş-aile çatışması ile aile-iş çatışması birbirinden farklı konular olarak görülse de bu iki kavramın birbirinden ayrı düşünülmesi mümkün değildir. Bunlar birbiri ile ilgili, birbirinden ayrılmaz, birbiri içine girmiş (interrole) çatışmalardır (Netemeyer vd., 1996). Şöyle ki; işgörenin hem işyerine hem de ailesine karşı sorumlulukları bulunmaktadır ve bu sorumluluklardan birinin gerek zaman gerek ilgi açısından fazladan bir talebi, diğer rolün yerine getirilmesini zorlaştırmakta ve kişi üzerinde gerginlik yaratmaktadır. Birçok çalışmada da bu durum rol çatışması olarak ele alınmış ve yarattığı olumsuzluklar üzerinde durulmuştur (Waumsley vd., 2010; Akanji, 2012). İş de aile de insanların zaman ve enerji ayırması gereken önemli iki konudur. İște veya ailede harcanan zamanın ve enerjinin birbiri ile telafi edilmesi mümkün değildir. $\mathrm{Bu}$ nedenle iş-aile çatışması sıfır toplamlı, yıpratıcı bir konu olarak değerlendirilmiştir (Friedman vd., 1998; Edwards ve Rothbard, 2000). Bu bakış açısına sahip yaklaşımlarda iş-aile çatışması, işgörenin rollerini yerine getirme konusundaki yetersizliğinden kaynaklanan bir konu olarak ele alınmış (Ueda, 2012), "iş ve iş dışı rollere ait duygusal ve davranışsal ihtiyaçların uyumsuzluğu" olarak tanımlanmıştır (Allan vd., 2007, s. 220). Diğer bir anlatımla iş-yaşam çatışması, çalışanların, çalışan anne, baba, eş, arkadaş ve işgören gibi aynı anda birden fazla role sahip olması ve bu rollerin eş zamanlı olarak ortaya çıkması (Turunç ve Çelik, 2010; Jyothi ve Jyothi, 2012) nedeniyle yaşanan uyumsuzluk durumu olarak değerlendirilmiştir.

Greenhaus ve Beutell (1985)'e göre üç çeşit iş-yaşam çatışması söz konusudur: Zamana, gerilime ve davranışa dayalı çatışma. Zamana dayalı çatışma, mesai saatinin uzunluğu, çalışma programının esnekliği, evli veya bekâr olma durumu, işgörenin çocuğunun olup olmaması, eşinin çalışıp çalışmaması gibi işten veya aileden kaynaklanan ve işgörenin bunlara bağlı olarak herhangi bir rolü için zamanının yetmemesinden; gerilime dayalı çatışma, işgörenin gerek iş yerinde gerek aile ortamında yaşadığı olumsuz duygulardan, davranışa dayalı çatışma ise iş ve aile yaşamında farklı rolleri olan işgörenlerin bu rollerinin her biri için sergilemesi gereken davranışlarının birbiri ile uyumsuz olmasından kaynaklanmaktadır. Bu çatışmaların bir neticesi olarak işgörenlerin kendilerini sürekli telaş içinde ve zaman baskısı altında hissettiği, bu durumun kadınlar açısından daha yıpratıcı bir nitelik taşıdığı (Webber vd., 2010), işe bağlı stres, anksiyete, iştahsızlık, yorgunluk, depresyon gibi hem fiziksel hem psikolojik sağlık sorunlarına ve aile içi üzücü olaylara neden olduğu (Allen vd., 2000; Akanji, 2012; Haar, 2006), içki ve uyuşturucu bağımlılı̆̆1 yaptığı (Grunberg vd., 1998), bunların bir neticesi olarak da işten tatmin olmama, tükenmişlik ve işten ayrılma niyetinin ortaya çıktığı, haftalık çalışma saatinin 
aile-iş çatışmasından değil, iş-aile çatışmasıyla ilgili olduğu (Netemeyer vd., 1996) tespit edilmiştir. Bu araştırmalara alternatif olarak yapılan diğer çalışmalarda ise iş yaşam dengesinin işgörenlerin moralini yükselttiği, verimliliğini ve örgüte bağlılığını artırdığı, devamsızlığını azalttığı, kendilerini işlerine daha çok adayarak daha profesyonelce çalıştığını ve daha az hastalandığını, bunların neticesi olarak da işlerinde daha az stres yaşadığını (Narayanan ve Narayanan, 2012; Allen, 2001) ve tüm bunların da şirketin imajını olumlu yönde etkilediği, işgören devrinin azalması ile bağlantılı olarak da işe alma ve eğitim masraflarının azaldığı (Johnson, 2004) belirlenmiştir.

\section{İş-Yaşam Dengesi ile ilgili Yasal Düzenlemeler}

Gerek aile içinde gerek işyerinde yaşanan olumsuzlukların, işgörenler, işverenler ve toplum için olumsuz etkileri olabilir (Brummelhuis ve van der Lippe, 2010, s. 173). Bundan dolayı hükümetler de iş-yaşam dengesi konusunun önemine vurgu yapmaktadır. Örneğin, AB Komisyonu, 1993 yılında çıkardığı Çalışma Süresinin Düzenlenmesi Hakkındaki Yönerge ile fazla mesai dahil her 7 günlük dönemde ortalama çalışma süresinin 48 saati aşmaması konusunu hükme bağlamış (MESS, 2002, s. 28), Türk İş Kanunu'nda ise bu süre, fazla mesai de dahil olmak üzere haftada en fazla 45 saat olarak düzenlenmiştir (MESS, 2002, s. 45). Japonya'da da 2007 yılında yapılan bir yasal düzenleme ile, ailesine karşı sorumluluklarını yerine getirmek konusunda sorun yaşayan bir işgörenin, işvereninden iş saatlerini azaltması, çocuk bakımı için kısa süreli ve geçici olarak izin istemesi, fazla mesai saatlerinden muaf tutulması gibi konularda talepte bulunabilmesinin (Ueda, 2012) önü açılmıştır.

Bu kapsamda birçok şirket de hem yasaların bir gereği olarak hem de işgörenlerinin üretkenliğini artırmak ve yetenekli işgörenlerini elde tutmak maksadıyla mevcut iş yapma tarzlarında ve süreçlerinde, işgörenlerinin işyaşam dengesini sağlayacak şekilde düzenleme yapmış, bu konuyla ilgili çeşitli uygulamalar geliştirmiştir. Bu kapsamda esnek çalışma, üzerinde durulan önemli bir kavramdır ve zamanın ve işyerinin esnek hale getirilmesi, geçici veya sürekli yarı zamanlı olarak çalışma, iş paylaşımı, çalışma saatlerinin sıkıştırılması gibi hususları kapsamaktadır (Maruyama vd., 2009). Geleneksel ofiste çalışma ortamına ilave olarak, farklı teknolojilerin yardımıyla, işgörenin işini istediği yerde elektronik olarak yapmasını sağlayan uzaktan çalışma imkânı, büyük merkezileşmiş tesislerin parçalanarak işgörenlerin evlerine yakın görece daha küçük işyerlerinden oluşan şebeke şeklinde tertiplenmiş uydu ofislerin kurulması, işgörenin ihtiyaç duyduğu, bilgisayar, yazılım, telefon, faks vb. ofis cihaz ve malzemelerinin şirket tarafından temin edilerek işgörenlere evde çalışma imkanı verilmesi ya da tüm bu alternatiflerin karma bir şekilde uygulanması (Apgar IV, 1998) şirketlerin bu kapsamda yaptıkları düzenlemelerden bazılarıdır.

\section{İş-Yaşam Dengesi ile ilgili Uygulamalar}

Tüm bu bilgiler ışı̆ğında, işgörenler ve işgörenlerin iş dışı faaliyetleriyle ilgili tüm konuların iş-yaşam dengesi kapsamda değerlendirilmesi gerektiği, iş ve yaşamın birbirinden farkı alanlar olmadığı ve bundan dolayı kişiler tarafından dengelenebilmesi gerektiği, bu iki kavramın iç içe girdiği, bu birbirinin içine geçmiş yapıyı ifade etmek ve iş yaşam dengesini etkileyen bir çok faktörün bulunduğunu ifade etmek maksadıyla denge ifadesi yerine karşılıklı etkileşim (interaction) teriminin kullanılmasının daha uygun olacağ da belirtilmiştir (Webber vd., 2010). Bu bakış açısıyla iş ve kişisel yaşamın birbirine zıt kavramlar olmadığı, tersine birbirini tamamladığı kabul edilmiştir.

Friedman (1998) da yöneticilerin ve işgörenlerin iş hedefleri ile kişisel hedefler konusunda herkesin yararına olacak şekilde iş birliği yapmasını tavsiye etmekte, böylece iş yaşam çatışmasının iş yaşam dengesine dönüştürülebileceğini belirtmekte, bu konuda yöneticilerin yapması gereken hususları şu şekilde özetlemektedir: İlk olarak işgörenler iş öncelikleri konusunda bilgilendirilmeli, kendileri açısından önceliklerinin ne olduğunu açıklayabilmeleri konusunda teşvik edilmelidir. Yine işgörenlerin işyeri dışındaki 
diğer rolleri kabul edilerek, desteklenmelidir, kuruluşun performansını artıran ve aynı zamanda işgörenlerin kendi bireysel amaçlarını gerçekleştirmesini sağlayan, uygulamalara da yer verilmelidir. Diğer bir anlatımla, başarı işyerinde geçirilen zamana göre değil, elde edilen sonuçlara göre değerlendirilmelidir. Nitekim yapılan birçok araştırmada (Demir, 2010; Malone ve Raja, 2013; Sakthivel ve Kamalanabhan, 2011) iş-yaşam dengesi konusundaki örgütsel desteğin örgütsel bağllı̆̆g artırdığı ve işgörenlerin işlerini en iyi şekilde gerçekleştirmek konusunda motive ettiği tespit edilmiştir (Brummelhuis ve van der Lippe, 2010).

\section{İş-Yaşam Dengesi ve Çalışılan Sektör}

Akın, Ulukök ve Arar (2017) tarafından iş-yaşam dengesi üzerine Türkiye'de yapılan çalışmalara yönelik yapılan bir incelemede, iş yaşam dengesini konu alan 17'si tez ve 19'u makale olmak üzere, ulusal yazındaki toplam 36 çalışma değerlendirilmiştir. Buna göre; yapılan çalışmaların \%46’sı özel sektör, \%27’si kamu sektörü ve \%27'si da hem özel hem de kamu sektörü üzerinde yapılmıştır. Görüldüğü üzere bu konuda çalışan araştırmacılar iki sektöre (kamu ve özel) de eşit ağırlık vermemiştir. Konunun çoğunlukla özel sektörde araştırılmış olmasının, kamuya nispetle özel sektörde mesai saatlerinin kesin hatlarla belirlenmemiş olması ve artan rekabet koşullarının özel sektöre daha çok yansıması şeklinde açıklanmıştır (Akın, Ulukök ve Arar, 2017). Özellikle, özel sektördeki iş yoğunluğu mesai kavramını olumsuz etkileyerek iş-yaşam dengesini daha çok bozmaktadır (Gerçek vd., 2015). Topaloğlu, Sönmez ve Yazgan (2019) tarafından yoğun bir çalışan bankacılık sektörü üzerinde yapılan bir çalışmada da bankacılık sektöründe çalışmaya olan tutkunluk arttıkça yaşam odaklılığın arttığı belirlenmiştir. Yazında yapılan araştırmalar sektörel bazda genellikle örneklem boyutunda kalmasına rağmen önemli olduğu ve çalışılan sektörün iş-yaşam dengesinin, örgütsel sonuç değişkenleri üzerindeki etkisindeki rolünün yeterince incelenmediği görülmektedir.

\section{Yaşam Tatmini}

İş yaşamı, bireyler için çok önemli olsa da elbette yaşam sadece iş yaşamından ibaret değildir. Hatta iş yaşamının bir amaç değil, bir araç olduğu söylenebilir. Amaç, yaşamın bütününden tatmin olmaktır. Bu çerçevede yapılan bu araştırmanın bağımlı değişkeni yaşam tatminidir. Yaşam tatmini, örgütsel davranış kapsamında da önemli bir kavram olarak değerlendirilmektedir (Bekmezci ve Mert, 2018). Yaşam tatmini, bir insanın yaşamını beğenmesi, onaylaması ve yaşamından memnun olmasıdır (Haybron, 2007). Diener ve diğerlerine (1999) göre yaşam tatmini, kişinin yaşamını her yönüyle değerlendirmesinin bir sonucudur ve hayattaki beklentilerinin ne kadarının gerçekleştirildiği ile ilgili mevcut durumun değerlendirilmesi neticesinde ortaya çıar. Yaşam tatmini, yaşam kalitesinin sübjektif bir değerlendirmesidir (Myers ve Diener, 1995; Marques vd., 2007). Yaşam kalitesi de sağlıklı ve mutlu olmak, toplumun bir üyesi olmak gibi duyguları içeren hem sübjektif hem de objektif unsurlardan oluşur (Veenhoven, 2000). Yaşam tatmini, bilişsel bir durumdur, yaşamın bir bütün olarak değerlendirilmesidir ve kalıcıdır. Dolayısıyla yaşam tatmini, zevk ve neşe gibi kavramlardan ayrışır (Jagodzinski, 2010). Nitekim yaşam tatmini, günlük yaşamda mutluluk olarak bilinen (Çivitci, 2007; Eryllmaz ve Ögülmüş, 2010), öznel iyi-oluşun (subjective well-being) bir bileşeni olarak değerlendirilmektedir (Pavot ve Diener, 1993).

Öznel iyi-oluşun duygusal ve bilişsel olmak üzere iki boyutu bulunmaktadır. Öznel-iyi oluşun duygusal boyutu hoş ve nahoş duygular olmak üzere iki bölümde incelenmektedir. Bilişsel ya da yargılamaya dönük boyutu yaşam tatminine vurgu yapmaktadır (Pavot ve Diener, 1993; Gadermann vd., 2010; Hsieh, 2003; Ozben, 2013; Eryllmaz ve Öğülmüş, 2010). Lucas ve diğerleri (1996), hoş ve nahoş duygular ile yaşam tatmininin birbirinden ayrılabilir yapılara sahip olduğunu göstermiştir. Bundan dolayı, tatmin olma durumu, öznel iyi-oluş çalışmalarında, öznel iyi-oluşun duygusal boyutundan ayrı bir şekilde ele alınmıştır. Yaşam tatmininin öznel iyi-oluşun duygusal boyutundan ayrı ele alınmasının nedenleri arasında şu hususlar da bulunmaktadır: İnsanlar, kendi yaşamını olumsuz etkilemesine rağmen nahoş duyguları inkâr etme veya görmemezlikten gelme eğilimindedir. Duygusal tepkiler tatmin olma durumu ile karşılaştırıldığında genellikle tepkisel ve kısa 
sürelidir. Bunlara ilave olarak, insanlar hayatını, bilişsel değerlere ve amaçlarını gerçekleştirip gerçekleştiremediğine göre değerlendirmektedir (Pavot ve Diener, 1993). İnsanlar, iyi bir hayat kavramını genel bir değerlendirme yerine tek bir kritere bağlama eğilimindedir. Ancak bu kriterler herkes için farklıdır. Kriterler aynı olsa bile, kriterlerin standartları herkes için farklılık göstermektedir. Bundan dolayı Pavot ve Diener (1993), kişinin spesifik bir alanda tatmin olma durumunun incelenmesinden ziyade genel yaşam tatmini üzerinde durulması gerektiğine vurgu yapmıştır.

\section{Yaşam Tatmininin Ölçülmesine Yönelik Yaklaşımlar}

Yaşam tatmininin ölçülmesi ve kavramsallaştırılmasında, tavandan-tabana (top-down) ve tabandan-tavana (bottom-up) olmak üzere iki temel yaklaşım kullanılmaktadır (Saldamlı, 2008; Hsieh, 2003): Tavandan-tabana yaklaşımına göre yaşam tatmini, bireyin spesifik alanlardaki tatmin olma durumunu genelleştirmesinin bir sonucu olarak, kendisini mutlu veya mutsuz görmesidir. Bir kişinin, sosyal ilişkilerinin güzel olması, maddi sıkıntı içinde bulunmaması, iyi bir gelire sahip olması, işinin ilginç olması gibi hususlardan dolayı hayatından tatmin olması tavandan-tabana yaklaşımına örnek olarak verilebilir. Tabandan-tavana yaklaşımına göre yaşam tatmini, kişiliğin bir sonucudur ve bireyin herhangi bir konuda tatmin olma durumu da yaşam tatmininden etkilenir. Nevrotik bir kişinin genellikle kendi yaşamından, diğer insanlarla olan ilişkilerinden, gelirinden ve işinden tatmin olmaması veya çevresindeki diğer insanlara göre daha az tatmin olması tabandan-tavana yaklaşımına örnek olarak verilebilir.

\section{Yaşam Tatmini ile ilgili Yapılan Araştırmalar}

Yaşam tatmini ile ilgili yapılan araştırmaların yetişkinlerle ilgili konulara yoğunlaştığı görülmekle birlikte (Greenspoon ve Saklofske, 1998), çocuklar, gençler, yaşlllar, hamile kadınlar, göçmenler, psikiyatrik sorunu olmayan ayakta tedavi gören hastalar gibi farklı gruplar üzerinde de bu konuyla ilgili incelemeler yapılmıştır (Gouveia vd., 2009). Kişilerarası ilişkiler (interpersonal), kişinin kendi iç dünyası (intrapersonal), iş, fiziksel ve psikolojik sağlık ile eğitim durumu yaşam tatminini etkileyen hususlardır (Marques vd., 2007). İnsanların istekleri veya arzuları ile mevcut durumu arasındaki farklılık arttıkça yaşam tatmininin de o kadar düşük olduğu görülmüștür (Lavallee vd., 2006).

Yaşam tatmininin belirlenmesinde; iş tatmininin, geçmişe dönük pişmanlıkların ve boş zamanlarda yapılan faaliyetlerin de büyük bir öneme sahip olduğu görülmüştür (Akın, 2008). Diğer bir anlatımla yaptığı işten tatmin olan, geçmişte yaptıklarından pişman olmayan veya diğer insanlara göre daha az pişman olan, boş vakitlerinde sevdiği işlerle uğraşan insanların yaşam tatmininin daha yüksek olduğu söylenebilir. Diener (1994), insanların yaşam tatminindeki farklılı̆̆ın yarısına yakınının genetik unsurlardan kaynaklandığını, davranışların yaşam tatminini tahmin etme konusunda önemli ipuçları sağladığını belirtmektedir (aktaran Baş, 2011).

Adler (1995, s. 1)'e göre insan, yeterli olma, başarılı olma veya üstün olma gibi duygularla dünyaya gelmiştir. İnsanın bu duyguları ve bu duygular için göstermiş olduğu çaba, kişinin kendisini ve yaşamını oluşturmaktadır. Adler’in üstün olma duygusundan kastı toplum içinde ayrıcalık kazanmak değil, bireyin kendi kendini gerçekleştirmesidir. Dolayısıyla bireyin sahip olduğu bu duyguların icraata dökülmesi ve bu konularda kişinin kendini başarılı görmesi de yaşam tatminini etkileyecektir. İnsanların istekleri ile elde ettikleri arasında ne kadar uyum varsa, yaşam tatmini de o kadar artmaktadır (Diener vd., 2003). İnsanların bir amacının olması, amacını gerçekleştirebileceğine inanması ve amacını gerçekleştirmek konusunda gösterdiği çabayı kararlı bir şekilde sürdürmesi yaşam tatminini artırmaktadır (İlhan ve Özbay, 2010). Dolayısıyla yaşam tatmini, bir anlamda bireyin hedeflerine ulaşma derecesidir (Özdevecioğlu ve Doruk, 2009). Nitekim Jagodzinski (2010) de yaşam tatmininin bugünün ve yarının amaç ve isteklerinin kişisel beklentileri karşılaması veya bu amaçların karşılanması ile direkt ilgisi olduğuna vurgu yapmıştır. 
Yaşam tatmininin, bazı sosyo-demografik unsurlarla da ilişkili olduğu belirlenmiştir. Bunlar arasında, gelir düzeyi (Bowman, 2000; Myers ve Diener, 1995; Diener vd., 1993), kültür (Oishi, 2006), medeni durum (Dockery, 2005), iş tatmini (Yiğit vd., 2011; Özdevecioğlu ve Doruk, 2009; Aşan ve Erenler, 2008; Saldaml, 2008; Keser, 2005; Tait vd., 1989; Rice vd., 1980), kişilik özelliği ve değerleri (Perrone, 2007), , bireyin kurumdaki mevkisi (Dockery, 2005; Yiğit vd., 2011), sosyal destek (Dockery, 2005; Baş, 2011), eğitim düzeyi (King, 1987) sayllabilir.

Myers ve Diener (1995)'e göre; cinsiyet, ırk ve gelir durumu yaşam tatmini ile mutluluğu yordamamaktadır. Kişisel eğilim, ilişkiler ve kültür gibi değişkenlerin yaşam tatminini açıklama konusundaki etkisi daha fazladır. Ancak Bayram ve diğerleri (2010), 2493 kişi üzerinde yaptığı araştırma neticesinde kadınların, eğitim düzeyi ile aylık geliri yüksek olanların, Keser (2005) ve Gençay (2009) da yine kadınların erkeklere göre daha yüksek yaşam tatminine sahip olduğunu tespit etmiştir. Baş (2011), 272 öğretmen adayı üniversite öğrencisi ile Özben (2013) ise 525 üniversite öğrencisi ile yaptığı araştırmanın neticesinde, kız öğrencilerin yaşam tatmin puanlarının erkek öğrencilerinkinden daha yüksek olduğunu bulmuştur. Aşan ve Erenler (2008) ise yaşam tatmini konusunda cinsiyet açısından bir farklılık tespit edememiştir. Diğer taraftan yapılan kesitsel (crosssectional) çalışmalar, genel yaşam tatmini düşük olan yetişkinlerin intihar düşüncesine sahip olduğunu ve intihar davranışı sergilediğini, bu kişilerin akıl sağlığının bozuk olduğunu göstermiş, yine kişilerin tütün, alkol ve kokain gibi madde kullanımı da yaşam tatmininin düşüklüğü ile ilişkilendirilmiştir (Gadermann vd., 2010). İlgili yazın sonucunda hipotezler şu şekilde belirlenmiştir:

H1: İşin, kişisel yaşama etkisi yaşam tatminini negatif bir şekilde etkilemektedir.

H2: Kişisel yaşamın işe etkisi yaşam tatminini negatif bir şekilde etkilemektedir.

H3: Çalışlan sektörün (kamu ve özel), işin kişisel yaşama etkisi ile yaşam tatmini arasındaki ilişkide düzenleyici etkisi vardır.

H4: Çalışılan sektörün (kamu ve özel), kişisel yaşamın işe etkisi ile yaşam tatmini arasındaki ilişkide düzenleyici etkisi vardır.

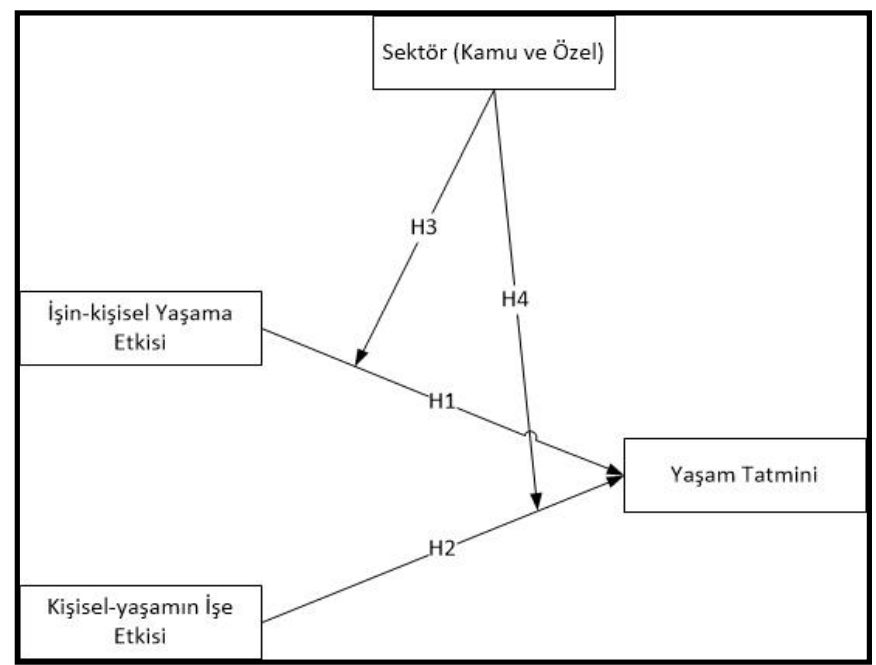

Şekil 1. Araştırma Modeli 


\section{Yöntem}

İş-yaşam dengesinin iş tatminini yordamasında işgörenlerin çalıştığı sektörün düzenleyici etkisini tespit etmek için yapılan bu araştırmada, önce örneklem ve veri toplamak için kullanılan ölçekler hakkında bilgi verilmiş, daha sonra kurulan model ile ilgili yapılan analizlere yer verilmiştir. Bu kapsamda, doğrulayıcı faktör analizi yapıldıktan sonra değişkenler arasındaki korelasyona bakılmıştır. Analizler için SPSS ve AMOS programları kullanılmıştır.

\section{Araştırmanın Örneklemi}

Araştırmanın evrenini Ankara ve İstanbul'da kamu ve özel sektörde faaliyet gösteren toplam 10 kurum/şirket oluşturmaktadır. Bu kapsamda, 10 kurum/şirkette çalışan toplam 1100 kişi kolayda örneklem yöntemiyle örneklem olarak seçilmiştir. Katılımcılara gönderilen 1100 anketten, 679'undan cevap alınmıştır. Anketlerin geri dönüş oranı \%62'dir. Ancak, 57 anket değerlendirme dışı bırakılmıştır. Dolayısıyla analize tabi tutulan anket formu sayısı 622 olarak belirlenmiştir. Araştırmaya katılan kişilerin demografik bilgileri Tablo 1'de özetlenmiştir:

Tablo 1

Katılımcıların Demografik Özellikleri

\begin{tabular}{llcc}
\hline \multirow{3}{*}{ Cinsiyet } & & Frekans & $\mathbf{\%}$ \\
\hline & Erkek & 482 & 77.7 \\
\cline { 2 - 4 } & Kadın & 139 & 22.3 \\
\cline { 2 - 4 } Eş çalıșma durumu & Toplam & $\mathbf{6 2 2}$ & $\mathbf{1 0 0 . 0}$ \\
\cline { 2 - 4 } & Evli değilim & 305 & 49.0 \\
\cline { 2 - 4 } & Çalışıyor & 194 & 31.2 \\
\cline { 2 - 4 } & Çalışmıyor & 123 & 19.8 \\
\cline { 2 - 4 } Çocuk sayısı & Toplam & $\mathbf{6 2 2}$ & $\mathbf{1 0 0 . 0}$ \\
\hline \multirow{3}{*}{ Çocuk sahibi olmayan } & 364 & 58.5 \\
\cline { 2 - 4 } & Çocuk sahibi olan & 258 & 41.5 \\
\cline { 2 - 4 } & Toplam & $\mathbf{6 2 2}$ & $\mathbf{1 0 0 . 0}$ \\
\hline
\end{tabular}

\section{Kavramsal Model ve Ölçekler}

Kavramsal model oluşturulurken daha önce yapılmış araştırmalarda geliştirilmiş modeller temel alınmıştır. İş̧yaşam dengesini ölçmek için Netemeyer ve diğerleri (1996) tarafından geliştirilen ve Türkçe geçerlemesi makalenin yazarları tarafından yapılmış olan ölçek kullanılmıştır. Ölçek, işin kişisel yaşama etkisi ve kişisel yaşamın işe etkisi olmak üzere 2 boyuttan ve 10 ifadeden oluşmaktadır. Ölçekte yer alan bazı ifadeler "İşimin gerekleri, iş dışındaki hayatımı sınırlandırıyor.", "İşime ayırdığım zaman, diğer ilgi alanlarıma yönelmemi zorlaştırıyor." şeklindedir. Yaşam tatminini ölçmek için Diener ve diğerleri (1985) tarafından geliştirilen, Türkçe geçerlemesi Bekmezci ve Mert (2018) tarafından yapılmış olan ölçek kullanılmıştır. Ölçek tek boyuttan ve 5 ifadeden oluşmaktadır. Ölçekte yer alan bazı ifadeler "İdeallerime yakın bir hayatım var.", "Hayat koşullarım mükemmeldir.” şeklindedir. Ölçekler 7’li Likert ölçeğine göre düzenlenmiştir. Araştırmanın kavramsal modeli Şekil 1'de sunulmuştur. 


\section{Bulgular}

$\mathrm{Bu}$ aşamada gözlenen değişkenlerin gizli değişkenleri temsil etme durumunu belirlemek amacıyla doğrulayıcı faktör analizi (DFA) yapılmıştır (Hair vd., 2010). DFA ile araştırma modelinin veriye uygun olup olmadığını tespit etmek için, üç indeks kullanılmış ve şu sonuçlara ulaşılmıştır: $\Delta \chi^{2} / \mathrm{df}=2.948, \mathrm{GFI}=0.949, \mathrm{NFI}=0.957$, $\mathrm{CFI}=0.971$, RMSEA = 0.056. Elde edilen bu sonuçlar neticesinde çalışmaya üç faktörlü (ilişkili) model ile devam edilmiştir. Maksimum Benzerlik Tahmini (MLE) kullanılarak gerçekleştirilen DFA çıktılarına göre maddelerin standartlaştırılmış faktör yüklerinin 0.626 ile 0.902 arasında değiştiği ve istatistiksel olarak anlamlı olduğu tespit edilmiştir. $\mathrm{Bu}$ yüklerin 0.5 değerinden büyük olması yakınsama geçerliliğinin sağlandığını göstermektedir (Hair vd., 2010; Abubakar vd., 2017; Bentler ve Bonett, 1980; Bollen, 1989). DFA sonuçları Şekil 2'de sunulmuştur.

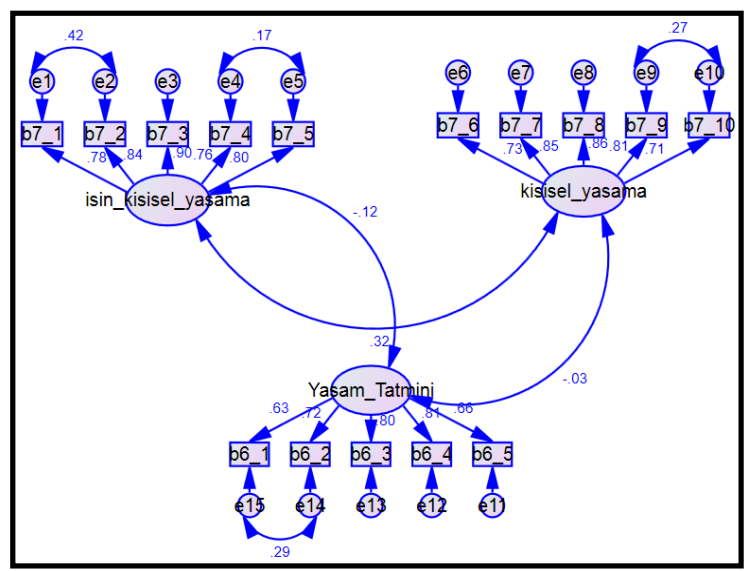

Şekil 2. Doğrulayıcı Faktör Analizin Çıktıları

Kullanılan araçların, ölçmeye yöneldiği yapıyı ölçüp ölçmediğine ilişkin yapı geçerliği; 1) yakınsama geçerliği (Convergent validity) ve (2) Iraksama ve ayırt edici geçerlilik (Divergent validity) teknikleri ile irdelenmiştir. Ortalama açıklanan varyans (Average Varianca Extracted (AVE)) değerlerinin 0.50'nin üzerinde olması yakınsama geçerliliğini; Maksimum Paylaşılan Varyansın Karesinin (Maximum Squared Variance (MSV)) AVE'den küçük olması ve AVE’nin karekökünün de faktörler arası korelasyondan büyük olması da iraksak ve ayırt edici geçerliliği göstermektedir (Anderson ve Gerbing, 1988; Fornell ve Larcker, 1981).

İçsel tutarlılık düzeyleri (Cronbach's alpha) ve yapı güvenirliği (Composite Reliability (CR)) değerlerinin 0.70'in üzerinde olması iç güvenilirliğin yeterli düzeyde olduğunu göstermektedir (Fornel ve Larcker, 1981). Yakınsama ve ıraksama geçerliliğinin sağlandığı Tablo 2'de gösterilmiştir. Elde edilen korelasyon katsayılarına bakıldığında, değişkenler arasındaki ilişkinin güçlü ve anlamlı olduğu söylenebilir. 
Tablo 2

Değişkenlere Ait Uyuşma Geçerliliği, Ortalama, Standart Sapma ve Korelasyon Değerleri

\begin{tabular}{lccccc}
\hline Değişkenler & Ort. & $\begin{array}{c}\text { S. } \\
\text { Sapma }\end{array}$ & $\mathbf{1}$ & $\mathbf{2}$ & $\mathbf{3}$ \\
& & & & & \\
\hline $\begin{array}{l}\text { 1.İşin Kişisel } \\
\text { Yaşama Etkisi }\end{array}$ & 4.374 & 1.632 & $(.820)$ & & \\
& & & & & \\
\hline $\begin{array}{l}\text { 2.Kişisel Yaşamın } \\
\text { İşe Etkisi }\end{array}$ & 2.700 & 1.396 & $.303^{* *}$ & $(.794)$ & \\
\hline 3.Yaşam Tatmini & 4.662 & 1.267 & $-.121^{* *}$ & -.030 & $(.727)$ \\
\hline $\begin{array}{l}\text { Cronbach's } \alpha \\
\text { Birleşik Güvenilirlik (CR) }\end{array}$ & & .917 & .897 & .846 \\
\hline $\begin{array}{l}\text { Ortalama Açıklanan Varyans (AVE) } \\
\text { Maksimum Paylaşılan Varyansın Karesi } \\
\text { (MSV) }\end{array}$ & .104 & .672 & .630 & .528 \\
\hline
\end{tabular}

Not: ${ }^{* *} \mathrm{p}<.01$; Parantez içindeki değereler AVE’nin karekökünü göstermektedir.

Çalışma kapsamında iddia edilen hipotezleri test etmek için yapılan yapısal eşitlik modeline ait sonuçlar Tablo 3’te sunulmuştur.

Tablo 3

Maksimum Benzerlik Tahmini Değerleri

\begin{tabular}{llccc}
\hline $\begin{array}{l}\text { Bağımsız } \\
\text { Değişkenler }\end{array}$ & Bağımlı Değişkenler & $\begin{array}{c}\boldsymbol{\beta}- \\
\text { değeri }\end{array}$ & S. Hata & $\begin{array}{c}\text { t- } \\
\text { değeri }\end{array}$ \\
\hline $\begin{array}{l}\text { İşin Kişisel } \\
\text { Yaşama Etkisi }\end{array}$ & Yaşam Tatmini & $-.123^{* *}$ & .031 & -3.085 \\
\hline Kişisel & Yaşam Tatmini & .007 & .036 & .187 \\
$\begin{array}{l}\text { Yaşamın İşe } \\
\text { Etkisi }\end{array}$ & & & & \\
\hline
\end{tabular}

Not: ${ }^{* *} \mathrm{p}<.01$

İşin kişisel yaşama etkisi, yaşam tatmini üzerinde negatif yönde ve anlamlı bir etkiye sahiptir $(\beta=-.123, \mathrm{p}<.01)$. Yani, işin kişisel yaşama etki düzeyi arttıkça yaşam tatmini azalmaktadır. Bu durum birinci hipotezin desteklendiğini göstermektedir. Kişisel yaşamın işe etkisinin yaşam tatmini üzerinde anlamsız ve negatif yönde bir etkisinin olduğu ifade edilebilir $(\beta=.007, \mathrm{p}>.10)$. Diğer bir anlatımla, kişisel yaşamın işe etkisinin artması işgörenlerin yaşam tatmininin azalmasına neden olmamaktadır. Bu durum ikinci hipotezin reddedildiğini göstermektedir. Sektörün (kamu ve özel) düzenleyici etkisini test etmek için çoklu-grup yapısal eşitlik modeli kullanılmıştır. Yapısal eşitlik modelinin uzantısı olan çoklu-grup SEM, farklı gruplarda aynı modeli test etmek için kullanılan son derece güçlü bir yöntemdir.

Bu amaçla örneklem; (1) kamu ve (2) özel sektör olmak üzere iki gruba ayrılmış ve işin-kişisel yaşama etkisi ve kişisel-yaşamın işe etkisi, yaşam tatmini üzerindeki etkisinin nasıl farklılaştığı bu iki grup için test edilmiştir. İlk olarak, sınırlandırılmamış (Unconstrained model) ve sınırlandırılmış model (Constrained model) test edilmiştir, daha sonra iki modelin $\chi^{2}$ değerlerinin farkı alınarak mukayese edilmiştir. Model farklılık göstermemiştir, ancak sektörün, işin-kişisel yaşama etkisi ve yaşam tatmini arasındaki ilişkide anlamlı 
düzenleyici etkisinin varlığını göstermektedir. Diğer bir ifade ile işin-kişisel yaşama etkisi yaşam tatmini üzerindeki etkisi, kamu işgörenlerinde daha fazladır. Bu sonuç önerilen üçüncü hipotezin desteklendiğini, dördüncü hipotezin de reddedildiğini göstermektedir (Bk. Tablo 4).

Tablo 4

Çok-gruplu Düzenleyici Analizi Sonuçları

\begin{tabular}{|c|c|c|c|c|}
\hline $\begin{array}{c}\text { Bağımsız } \\
\text { Değişkenler }\end{array}$ & $\begin{array}{c}\text { Bağımlı } \\
\text { Değişkenler }\end{array}$ & $\begin{array}{c}\text { ק-değeri } \\
\text { (Kamu, } \\
\text { n=217) }\end{array}$ & 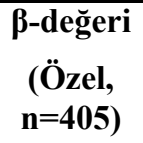 & $\begin{array}{c}\chi^{2}- \\
\text { değeri }\end{array}$ \\
\hline $\begin{array}{l}\text { İşin Kişisel } \\
\text { Yaşama } \\
\text { Etkisi }\end{array}$ & $\begin{array}{l}\text { Yaşam } \\
\text { Tatmini }\end{array}$ & $-.127 * * *$ & $-.117 * * *$ & $63^{*}$ \\
\hline $\begin{array}{l}\text { Kişisel } \\
\text { Yaşamın İşe } \\
\text { Etkisi }\end{array}$ & $\begin{array}{l}\text { Yaşam } \\
\text { Tatmini }\end{array}$ & -.083 & .055 & 60 \\
\hline
\end{tabular}

\section{Sonuç ve Tartışma}

Yapılan bu araştırmada, iş-yaşam dengesinin yaşam tatminini yordamasında işgörenlerin çalıştı̆̆ sektörün düzenleyici rolü araştırılmıştır. Analiz sonuçları incelendiğinde; işin kişisel yaşama etkisinin yaşam tatminini azalttığı, çalışlan sektörün (kamu-özel) iş yaşam dengesi ve yaşam tatmini arasındaki ilişkide düzenleyici bir etkiye sahip olduğu, kamu sektöründe çalışanlarda iş-yaşam çatışmasının (işin kişisel yaşama etkisi) yaşam tatminini daha fazla azalttığı, kişisel yaşamın işe etkisinin ise yaşam tatminini etkilemediği belirlenmiştir. Elde edilen bu bulgular, önceden yapılan bazı araştırmalarla uyumluluk göstermektedir (Örneğin Karatepe ve Bekteshi, 2008; Marks ve MacDermid, 1996).

Sonuç olarak; işin kişisel yaşamı etkilemesi, kişinin kendisine, ailesine, sosyal ilişkilerine yansıyacaktır. Özel yaşamında istediklerini yapma konusunda engellendiğini düşünen çalışanın mutlu olması mümkün değildir. Özel yaşamında mutlu olmayan çalışan iş yerinde de mutlu olmayacak, dolayısıyla işinden de tatmin olmayacaktır. İşinden tatmin olmayan çalışanlar ise örgüt tarafından arzu edilmeyen davranışlar sergilemeye başlayacaktır. Dolayısıyla insanların özel yaşamında da bireysel ihtiyaçlarını karşılayabilecek imkânların sağlanması gerekmektedir. Mutlu çalışanların performansının yüksek olmasının yanında, örgüte bağlılığı da artacaktır. İşin kişisel yaşamı etkilemesinin kamuda daha fazla olması, kamu kurumlarının tamamında uygulanan standartların, kişinin çalıştı̆̆ı kurumda uygulanmamasından kaynaklanabilir. Bu kapsamda kamu kurumlarında da kurallara uyulmalı, personele adil davranılmalı ve işler eşit olarak dağıtılmalıdır.

$\mathrm{Bu}$ araştırmanın bazı sınırlılıkları bulunmaktadır. Araştırmada kolayda örneklem yoluyla veri toplanması araştırmanın önemli bir kısıtıdır. Araştırmanın boylamsal olmaması, araştırmanın sadece Ankara ve İstanbul'da yapılmış olması diğer bir kısıttır. Bu nedenle araştırmanın farklı zaman aralıkları ile kamu ve özel sektörün de alt sektörlerini de inceleyecek şekilde daha kapsamlı olarak yapılmasına ihtiyaç olduğu değerlendirilmektedir. 


\section{Kaynakça}

Abubakar, A. M., Ilkan, M., Al-Tal, R. M. ve Eluwole, K. K. (2017). eWOM, revisit intention, destination trust and gender. Journal of Hospitality and Tourism Management, 31, 220-227. doi: 10.1016/j.jhtm.2016.12.005

Adams, G. A., King, L. A. ve King, D. W. (1996). Relationships of job and family involvement, family social support, and work-family conflict with job and life satisfaction. Journal of Applied Psychology, 81(4), 411-420. doi: 10.1037//0021-9010.81.4.411.

Adler, A. (1995). İnsan tabiatını tanıma (2.b.). Ayda Yörükan (Çev.), İstanbul: Türkiye İş Bankası.

Akanji, B. (2012). Realities of work life balance in Nigeria: Perceptions of role coflict and coping beliefs. Business, Management and Education, 10(2), 248-263. doi: 10.3846/bme.2012.18.

Akın, M. (2008). Örgütsel destek, sosyal destek ve iş/aile çatışmalarının yaşam tatmini üzerindeki etkileri. Bozok Üniversitesi Sosyal Bilimler Enstitüsü Dergisi, 25(2), 141-170. Erişim adresi: https://dergipark.org.tr/en/download/article-file/219452

Akın, A., Ulukök, E. ve Arar, T. (2017). İş-Yaşam dengesi: Türkiye'de yapılan çalışmalara yönelik teorik bir inceleme. Afyon Kocatepe Üniversitesi İktisadi ve İdari Bilimler Fakültesi Dergisi, 19(1), 113-124. Erişim adresi: https://dergipark.org.tr/tr/pub/akuiibfd/issue/29881/321965

Akter, K., Ali, M. ve Chang, A. (2019). Work-life programs and performance in Australian organisations: The role of organisation size and industry type. Asia Pacific Journal of Human Resources, 1-23. doi: $10.1111 / 1744-7941.12235$

Allan, C., Loudoun, R. ve Peetz, D. (2007). Influences on work/non-work conflict. Journal of Sociology, 43(3), 219-239. Erişim adresi: https://www.researchgate.net/publication/283288082_Influences_on_worknon-work_conflict

Allen, T. D., Herst, D. E., Bruck, C. S. ve Sutton, M. (2000). Consequences associated with work-to-family conflict: A review and agenda for future research. Journal of Occupational Health Psychology, 52(2), 278-308. doi: 10.1037//1076-8998.5.2.278.

Allen, T. D. (2001). Family supportive work environments: The role of organizational perceptions. Journal of Vocational Behavior, 58, 414-435. doi: 10.1006/jvbe.2000.1774.

Anderson, J. C. ve Gerbing, D. W. (1988). Structural equation modeling in practice: A review and recommended two-step approach. Psychology Bulletin, 103(3), 411-433. doi: 10.1037/00332909.103.3.411.

Apgar IV, M. (1998). The alternative workplace: Changing where and how people work. Harvard Business Review, 76(3), 121-136. Erişim adresi: https://hbr.org/1998/05/the-alternative-workplace-changingwhere-and-how-people-work

Aşan, Ö. ve Erenler, E. (2008). İş tatmini ve yaşam tatmini ilişkisi. SDÜ İIBF Dergisi, 13(2), 203-216. Erişim adresi: https://dergipark.org.tr/tr/download/article-file/194741

Baş, A. U. (2011). Investigating levels and predictors of life satisfaction among prospective teachers. Eurasian Journal of Educational Research, 44(Summer), 71-88. Erişim adresi: http://ejer.com.tr/en/archives/2011-summer-issue44/investigating-levels-and-predictors-of-lifesatisfaction-among-prospective-teachers-2761/

Batt, R. ve Valcour, P. M. (2003). Human resources practices as predictors of work-family outcomes and employee turnover. Industrial Relations, 42(2), 189-220. doi: 10.1111/1468-232X.00287 
Barnett, R. C. ve Hyde, J. S. (2001). Women, men, work, and family: An expansionist theory. The American Psychologist, 56(10), 781-796. doi: 10.1037/0003-066X.56.10.781.

Bayram, N., Sam, N., Aytaç, S. ve Aytaç, M. (2010). Yaşam tatmini ve sosyal dışlanma. "Işs, Güç" Endüstri İlişkileri ve İnsan Kaynakları Dergisi, 12(4), 79-92. doi: 10.4026/1303-2860.2010.0159.x.

Bekmezci, M. ve Mert, İ. S. (2018). Yaşam tatmini ölçeğinin Türkçe geçerlilik ve güvenilirlik çalışması. Toros Üniversitesi İISBF Sosyal Bilimler Dergisi, 5(8), 166-177. Erişim adresi: https://acikerisim.toros.edu.tr/xmlui/handle/1/230

Bentler, P. M. ve Bonett, D. G. (1980). Significance tests and goodness of fit in the analysis of covariance structures. Psychological Bulletin, 88(3), 588-606. doi: 10.1037/0033-2909.88.3.588.

Bollen, K. A. (1989). Structural equations with latent variables. New York: Wiley.

Bowman, S. (2000). Career success and life satisfaction for female and male healthcare managers. Hospital Topics, 78(3), 5-11. doi: 10.1080/00185860009596553.

Brummelhuis, L. T. ve van der Lippe, T. (2010). Effective work-life balance support for various houshold structures. Human Resource Management, 49(2), 173-193. doi: 10.1002/hrm.20340.

Casper, W. J., Weltman, D. ve Kwesiga, E. (2007). Beyond family friendly: The construct and measurement of singles-friendly work culture. Journal of Vocational Behavior, 70, 478-501. doi: 10.1016/j.jvb.2007.01.001.

MESS (2002). Çalışma sürelerinde esneklik. İstanbul: MESS.

Çivitci, A. (2007). Çok boyutlu öğrenci yaşam doyumu ölçeğinin Türkçe’ye uyarlanması: Geçerlik ve güvenirlik çalışmaları. Eurasian Journal of Educational Research, 26, 51-60. Erişim adresi: http://ejer.com.tr/en/archives/2007-winter-issue-26/

Demir, N. (2010). Küçülmeye giden işletmelerde geri kalanların yaşadıkları tükenme sendromunun örgüte bağlllık üzerindeki etkisi. Öneri: Marmara Üniversitesi Sosyal Bilimler Enstitüsü Dergisi, 9(33), 185198. Erişim adresi: https://dergipark.org.tr/tr/download/article-file/165679

Diener, E. D., Emmons, R. A., Larsen, R. J. ve Griffin, S. (1985). The satisfaction with life scale. Journal of Personality Assessment, 49, 71-75. doi: 10.1207/s15327752jpa4901_13.

Diener, E., Sandvik, E., Seidlitz, L. ve Diener, M. (1993). The relationship between income subjective wellbeing: Relative or absolute?. Social Indicatos Research, 28, 195-223. doi: 10.1007/BF01079018.

Diener, E., Suh, E. M., Lucas, R. E. ve Smith, H. L. (1999). Subjective well-being: Three decades of progress. Psychological Bulletin, 125(2), 276-302. doi: 10.1037/0033-2909.125.2.276.

Diener, E., Oishi, S. ve Lucas, R. E. (2003). Personality, culture, and subjective well-being: Emotional and cognitive evaluations of life. Annual Review of Psychology, 54, 403-425. doi: 10.1146/annurev.psych.54.101601.145056.

Dockery, M. (2005). Happiness, life satisfaction, and the role of work: Evidence from two Australian surveys. Perth: Curtin University of Technology.

Edwards, J. R. ve Rothbard, N. P. (2000). Mechanisms linking work and family: Clarifying the relationship between work and family constructs. Academic of Management Review, 25, 178-199. doi: $10.2307 / 259269$ 
Eryılmaz, A. ve Öğülmüş, S. (2010). Ergenlikte öznel iyi oluş ve beş faktörlü kişilik modeli. Ahi Evran Üniversitesi Eğitim Fakültesi Dergisi, 11(3), 189-203. Erişim adresi: https://dergipark.org.tr/tr/pub/kefad/issue/59502/855340

Friedman, S. D., Christensen, P. ve DeGroot, J. (1998). Work and life: The end of zero-sum game. Harvard Business Review, 76, 119-129. Erişim adresi: http://worklife.wharton.upenn.edu/wpcontent/uploads/2012/11/Friedman-et-al-The-End-of-the-Zero-Sum-Game-HBR-19981.pdf

Fornell, C. ve Larcker, D. (1981). Evaluating structural equation models with unobservable and measurement error. Journal of Marketing Research, 18(1), 39-50. doi: 10.2307/3151312.

Frone, M. R., Russell, M. ve Cooper, M. L. (1992). Prevalence of work-family conflict: Are work and family boundaries asymmetrically permeable. Journal of Organizational Behavior, 13(7), 723-729. doi: 10.1002/job.4030130708.

Gadermann, A. M., Schonert-Reichl, K. A. ve Zumbo, B. D. (2010). Investigating validity evidence of the satisfaction with life scale adapted for children, Social Indicators Research, 96, 229-247. doi: $10.1007 / \mathrm{s} 11205-009-9474-1$

Gençay, S. (2009). Beden eğitimi öğretmen adaylarının umutsuzluk ve yaşam doyumlarının bazı değişkenler açısından incelenmesi. Elektronik Sosyal Bilimler Dergisi, 8(27), 380-388. Erişim adresi: https://dergipark.org.tr/tr/pub/esosder/issue/6141/82421

Gerçek, M., Elmas Atay, S. ve Dündar, G. (2015). Çalışanların iş-yaşam dengesi ile kariyer tatmininin, işten ayrılma niyetine etkisi. Kafkas Üniversitesi İktisadi ve İdari Bilimler Fakültesi Dergisi, 6(11), 67-86. Erişim adresi: https://www.researchgate.net/publication/326551071_CALISANLARIN_ISYASAM_DENGESI_ILE_KARIYER_TATMINININ_ISTEN_AYRILMA_NIYETINE_ETKISI_Merv e_GERCEK_Sevgi_ELMAS_ATAY_Gonen_DUNDAR

Gouveia, V. V., Milfont, T. L., da Fonseca, P. N. ve de Miranda Coelho, J. A. P. (2009). Life satisfaction in Brazil: Testing the psychometric properties of the satisfaction with life scale (SWLS) in five Brazilian samples. Social Indicators Research, 90, 267-277. doi: 10.1007/s11205-008-9257-0.

Greenspoon, P. J. ve Saklofske, D. H. (1998). Confirmatory factor analysis of the multidimensional students' life satisfaction scale. Personality and Individual Difference, 25, 965-971. doi: 10.1016/S01918869(98)00115-9.

Greenhaus, J. H. ve Beutell, N. J. (1985). Sources of conflict between work and family roles. Academy of Management Review, 10, 76-88. doi: 10.2307/258214.

Greenhaus, J. H. ve Powell, G. N. (2006). When work and family are allies: A theory of work-family enrichment. Academy of Management Review, 31(1), 72-92. doi: 10.5465/AMR.2006.19379625.

Grunberg, L., Moore, S. ve Greenberg, E. S. (1998). Work stress and problem alcohol behavior: A test of the spill-over model. Journal of Organizational Behavior, 19(5), 487-502. doi: 10.1002/(SICI)10991379(199809) 19:5<487::AID-JOB852>3.0.CO;2-Z.

Haar, J. M. (2006). The downside of coping: Work-family conflict, employee burnout and the moderating effects of coping strategies. Journal of Management and Organization, 12, 146-159. doi: $10.1017 /$ S1833367200004089.

Haar, J. M., Russo, M., Suñe, A., Ollier-Malaterre, A. (2014). Outcomes of work-life balance on job satisfaction, life satisfaction and mental health: A study across seven cultures. Journal of Vocational Behavior, 85, 361-373. doi: 10.1016/j.jvb.2014.08.010 
Hair, J. F., Anderson, R. E., Tatham, R. L. ve Black, W. C. (2010). Multivariate data analysis (5th Ed.). Upper Saddle River, NJ: Prentice Hall.

Haybron, D. (2007). Life satisfaction ethical reflection and the science of happiness. Journal of Happiness Studies, 8(1), 99-138. doi: 10.1007/s10902-006-9006-5.

Hsieh, C. M. (2003). Counting importance: The case of life satisfaction and relative domain importance. Social Indicators Research, 61(2), 227-240. doi: 10.1023/A:1021354132664.

İlhan, T. ve Özbay, Y. (2010). Yaşam amaçlarının ve psikolojik ihtiyaç doyumunun öznel iyi oluş üzerindeki yordayıcı rolü. Türk Psikolojik Danışma ve Rehberlik Dergisi, 4(34), 109-118. Erişim adresi: https://dergipark.org.tr/tr/download/article-file/200142

Jagodzinski, W. (2010). Economic, social, and cultural determinants of life satisfaction: Are there differences between Asia and Europe?. Social Indicators Research, 97, 85-104. doi: 10.1007/s11205-009-9555-1.

Johnson, K. (2004). Flexible working: Changing the manager's role. Management Decision, 42(6), 721-737. doi: 10.1108/00251740410542302.

Jyothi, S. V. ve Jyothi, P. (2012). Assessing work-life balance: From emotional intelligence and role efficacy of career women. Advances in Management, 5(6), 35-43. Erişim adresi: https://www.researchgate.net/publication/238597747_Assessing_Work-

Life_Balance_From_Emotional_Intelligence_and_Role_Efficacy_of_Career_Women

Karatepe, O. M. ve Bekteshi, L. (2008). Antecedents and outcomes of work-family facilitation and family-work facilitation among frontline hotel employees. International Journal of Hospitality Management, 27(4), 517-528. doi: 10.1016/j.ijhm.2007.09.004.

Keser, A. (2005). İş doyumu ve yaşam doyumu ilişkisi: Otomotiv sektöründe bir uygulama. Çalışma ve Toplum, 4, 77-95. Erişim adresi: https://www.acarindex.com/dosyalar/makale/acarindex-1423874182.pdf

King, W. (1987). Comparison of job satisfaction, life satisfaction, and performance of overeducated and other workers. Journal of Social Psychology, 125(5), 421-434. doi: 10.1080/00224545.1987.9713727.

Klun, S. (2008). Work-life balance is a cross-generational concern-and a key to retaining high performer at accenture. Global Business and Organizational Excellence, 27(6), 14-20. doi: 10.1002/joe.20229.

Kumari, L. (2012). Employees' contribution on work life balance and its relations with job satisfaction in Indian public sector banks. International Journal of Exclusive Management Research, 2, 1-13. Erişim adresi: https://ijemr.in/wp-content/uploads/2018/01/Employees-perception-on-Work-Life-Balance-andjob-satisfaction-in-Public-Sector-Banks.pdf

Lavallee, F. L., Hatch, P. M., Michalos, A. C. ve McKinley, T. (2006). Development of the contentment with life assessment scale (CLAS): Using daily life experiences to verify levels of self-reported life satisfaction. Social Indicators Research, 83, 201-244. doi: 10.1007/s11205-006-9054-6.

Leiter, M. P. ve Durup, M. J. (1996). Work, home and in-between a longitudinal study of spillover. Journal of Applied Behavioral Science, 32, 29-47. doi: 10.1177/0021886396321002.

Lucas, R. E., Diener, E. \& Suh, E. (1996). Discriminant validity of well-being measures. Journal of Personality and Social Psychology, 71, 616-628. doi: 10.1037//0022-3514.71.3.616.

Malone, E. K. ve Raja, R. A. (2013) Work-life balance and organizational commitment of women in the U.S. construction industry. Journal of Professional Issues in Engineering Education \& Practice, 139(2), 8798. doi: 10.1061/(ASCE)CO.1943-7862.0000809 
Marks, S. R. ve MacDermid, S. M. (1996). Multiple roles and the self: A theory of role balance. Journal of Marriage and the Family, 58(2), 417-432. doi: 10.2307/353506.

Marques, S. C., Pais-Ribeiro, J. L. ve Lopez, S. J. (2007). Validation of a Portuguese version of the students' life satisfaction scale. Applied Research in Quality of Life, 2, 83-94. doi: 10.1007/s11482-007-9031-5.

Maruyama, T., Hopkinson, P. G. ve James, P. W. (2009). A multivariate analysis of work-life balance outcomes from a large-scale telework programme. New Technology, Work and Employment, 24(1), 76-88. doi: 10.1111/j.1468-005X.2008.00219.x.

Nam, T. (2014). Technology use and work-life balance. Applied Research in Quality of Life, 9, 1017-1040. doi: 10.1007/s11482-013-9283-1

Mert, İ. S. ve Bekmezci, M. (2016). İki kariyerli aile çalışanlarında iş ve yasam tatmini. Türk Sosyal Bilimler Araştırmaları Dergisi, 1(1), 46-56. Erişim adresi: http://tursbad.hku.edu.tr/tr/download/articlefile/347235

Myers, D. G. ve Diener, E. (1995). Who is happy?. Psychological Science, 6, 10-19. doi: 10.1111/j.14679280.1995.tb00298.x.

Narayanan, A. G. V. ve Narayanan, R. L. (2012). An emprical study on factors affecting work-life balance of IT professionals. European Journal of Social Sciences, 31(3), 302-313. Erişim adresi: https://www.researchgate.net/publication/288389412_An_empirical_study_on_factors_affecting_wo rk-life_balance_of_IT_professionals

Netemeyer, R. G., Boles, J. S. ve McMurrian, R. (1996). Development and validation of work-family conflict and family-work conflict scales. Journal of Applied Psychology, 81(4), 400-410. doi: 10.1037/00219010.81.4.400.

Oishi, S. (2006). The concept of life satisfaction across cultures: An IRT analysis. Journal of Research in Personality, 40, 411-423. doi: 10.1016/j.jrp.2005.02.002.

Ozben, S. (2013). Social skills, life satisfaction and loneliness in Turkish university students. Social Behavior and Personality, 41(2), 203-214. doi: 10.2224/sbp.2013.41.2.203.

Önder, N. (2013). Türkiye'de kadın işgücünün görünümü. ÇSGB Çalışma Dünyası Dergisi, 1(1), 35-61. Erişim adresi: https://docplayer.biz.tr/30212-Turkiye-de-kadin-isgucunun-gorunumu.html

Özdevecioğlu, M. ve Doruk, N. Ç. (2009). Organizasyonlarda iş-aile ve aile-iş çatışmalarının çalışanların iş ve yaşam tatminleri üzerindeki etkisi. Erciyes Üniversitesi İIBF Dergisi, 33, 69-99. Erişim adresi: http://iibf.erciyes.edu.tr/dergi/sayi33/5.k\%FDs\%FDm.pdf

Pavot, W. ve Diener, E. (1993). Review of the satisfaction with life scale. Psychological Assessment, 5(2), 164172. doi: $10.1037 / 1040-3590.5 .2 .164$.

Pavot, W. ve Diener, E. (2008). The satisfaction with life scale and the emerging construct of life satisfaction. Journal of Positive Psychology, 3, 137-152. doi: 10.1080/17439760701756946

Perrone, K. (2007). Relationships between parental attachment, work and family roles, and life satisfaction. Career Development Quarterly, 55(3), 237-248. doi: 10.1002/j.2161-0045.2007.tb00080.x.

Perry-Smith, J. E. ve Blum, T. C. (2000). Research notes-work-family human resource bundles and perceived organizational performance. Academy of Management Journal, 43(6), 11-24. doi: 10.5465/1556339.

Rice, R. W., Near, J. ve Hunt, R. (1980). The job satisfaction-life satisfaction relationships: A review of emprical research. Basic and Applied Social Psychology, 1(1), 37-64. doi: 10.1207/s15324834basp0101_4. 
Sakthivel, R. ve Kamalanabhan (2011). Work life balance reflections on employee satisfaction. Serbian Journal of Management, 6(1), 85-96. doi: 10.5937/sjm1101085R

Saldamlı, A. (2008). Otel işletmelerinde bölüm yöneticilerinin iş ve yaşam tatminini belirlemeye yönelik bir alan araştırması. Marmara Üniversitesi İ̈BF Dergisi, 25(2), 693-719. Erişim adresi: https://dergipark.org.tr/tr/pub/muiibd/issue/484/4337

Shankar, T. ve Bhatnagar, J. (2010). Work life balance, employee engagement, emotional consonance/dissonance and turnover intention. The Indian Journal of Industrial Relations, 46(1), 7487. doi: $10.2307 / 25741098$.

Tait, M., Padgett, M. Y. ve Baldwin, T. T. (1989). Job and life satisfaction: A reevaluation of the strength of the relationship and gender effects as a function of date of the study. Journal of Applied Psychology, 74(3), 502-507. doi: 10.1037/0021-9010.74.3.502.

Topaloğlu, E. O., Sönmez, R. ve Yazgan A. E. (2019). Çalışmaya tutkunluk ve iş yaşam dengesi arasındaki ilişki: Banka çalışanları üzerine. Journal of BRSA Banking and Financial Markets, 13(1), 59-76. Erişim adresi: https://dergipark.org.tr/tr/pub/bddkdergisi/issue/57335/812493

Turunç, Ö. ve Çelik, M. (2010). Algılanan örgütsel desteğin çalışanların iş-aile, aile-iş çatışması, örgütsel özdeşleşme ve işten ayrılma niyetine etkisi: Savunma sektöründe bir araştırma. Atatürk Üniversitesi Sosyal Bilimler Enstitüsü Dergisi, 14(1), 209-232. Erişim adresi: https://dergipark.org.tr/tr/pub/ataunisosbil/issue/2825/38175

Türk Dil Kurumu (1998). Türkçe sözlük, Ankara: Türk Dil Kurumu.

Ueda, Y. (2012). The effects of the perception of work-life balance on acceptance of work arrangement request. International Business Research, 5(8), 24-32. doi: 10.5539/ibr.v5n8p24.

Umer, R. ve Zia-ur-Rehman, M. (2013). Impact of work life balance and work life conflict on the life satisfaction of working women: A case study of higher education sector of twin cities of Pakistan. Academic Research International, 4(5), 445-458. Erişim adresi: http://paper.researchbib.com/view/paper/9849

Veenhoven, R. (2000). The four qualities of life: Ordering concepts and measures of the good life. Journal of Happiness Studies, 1, 1-39. doi: 10.1007/978-94-007-5702-8_11.

Yiğit, R., Dilmaç, B. ve Deniz, M. E. (2011). İş ve yaşam doyumu: Konya Emniyet Müdürlügü alan araştırması. Polis Bilimleri Dergisi, 13(3), 1-18. Erişim adresi: https://www.researchgate.net/profile/BuelentDilmac2/publication/344434133_IS_VE_YASAM_DOYUMU_KONYA_EMNIYET_MUDURLUG U_ALAN_ARASTIRMASI/links/5f74cf4b92851c14bca34595/IS-VE-YASAM-DOYUMU-KONYAEMNIYET-MUeDUeRLUeGUe-ALAN-ARASTIRMASI.pdf

Waumsley, J. A., Houston, D. M. ve Marks, G. (2010). What about us? Measuring the work-life balance of people who do not have children. Review of European Studies, 2(2), 3-17. doi: 10.1016/j.sbspro.2013.04.243.

Webber, M., Sarris, A. ve Bessell, M. (2010). Organisational culture and the use of work-life balance initiatives: Influence on work attitudes and work-life conflict. The Australian and New Zealand Journal of Organisational Psychology, 3(54), 54-65. doi: 10.1375/ajop.3.1.54.

Young, M. (1999). Work-family baclash: Begging the question, what's fair?. Annals of the American Academy of Political and Social Science, 562, 32-46. doi: 10.1177/000271629956200103.

Zedeck, S. ve Mosier, K. (1990). Work in the family and employing organization. American Psychologist, 45, 240-251. doi: 10.1037/0003-066X.45.2.240. 


\section{Extended Abstract}

\section{Purpose}

Studies on the relationship between work-life balance and life satisfaction have been continued to increase in the literature. In today's dynamic world, the number of double career families are gradually increasing. As a result of this increase, the importance of work-life balance and its affects on life satisfaction have gained importance.

In this study, the effect of work-life and life-work conflict on the life satisfaction of public and private sector employees was investigated. The research questions were determined as:

- Does the effect of work on personal life affect life satisfaction?

- Does the effect of personal life on work affect life satisfaction?

- Also, in two above cases - which can be summarized as the effect of work-life balance on life satisfaction - does the sector in which the attendances are working (whether the public or private sector) has a moderating role on this effect (the effect of work-life balance on life satisfaction)?

\section{Design and Methodology}

The study is an applied quantitative study that aimed to answer the research questions via exploratory design. By applying Structural Equation Modelling (SEM), a multi-group structural equation model was used to test the regulatory impact of the sector (public and private). Multi-group SEM, which is an extension of the structural equation model, is an extremely powerful method used to test the same model in different groups.

The universe of the research consists of 10 institutions/companies operating in the public and private sectors in two big cities of Turkey, Ankara and Istanbul. In this regard, the study's universe totally consists 1100 employees that were working in the selected 10 institutions/companies. Convenience sampling method was selected as the sampling method. The questionnaires were sent to 1100 employees and 679 out of 1100 questionnaires were returned. The return rate of the surveys is $62 \%$. However, 57 questionnaires were excluded from the evaluation due to missing data. Therefore, the number of questionnaires analysed was $622 .$.

To measure the work-life balance, the scale developed by Netemeyer et al. (1996) was used. The scale was both translated and adapted by the authors in Turkish. The scale consists of two dimensions and 10 items that aim to measure the effect of work on personal life and the effect of personal life on work. An example items is "The requirements of my job limit my private life outside of work.". In order to measure life satisfaction, the scale developed by Diener et al. (1985) and validated in Turkish by Bekmezci and Mert (2018) was used.

\section{Findings}

In this study, the moderating role of the sector (in which employees were working- whether it is private or public) on the relationship between work-life balance and life satisfaction was investigated. The motivation behind the investigation of such a topic emerged from the existing literature. The studies on this subject highlight the existence and importance of the relationship between work-life balance and life satisfaction, and emphasize the need for a more comprehensive examination of this relationship (For example, Karatepe and Bekteshi, 2008; Adams et al., 1996; Greenhaus and Powell, 2006; Marks and MacDermid, 1996; Barnett and Hyde, 2001).

In the study, it was found that the effect of work on personal life has a negative and significant effect on life satisfaction $(\beta=-.123, \mathrm{p}<.01)$. In other words, life satisfaction decreases as the effect level of the job on personal 
life increases. It can be stated that the effect of personal life on work has a negative impact on life satisfaction $(\beta=.007, \mathrm{p}>$.10). In other words, increasing the impact of personal life on the job does not cause a decrease in the life satisfaction of the employees.

In sum, it was found that the effect of work on personal life decreases the life satisfaction level of the employees, also it was determined that the sector that worked (public-private) has a moderating effect in the relationship between work life balance and life satisfaction. In a clearer word, the work-life conflict (effect of work on personal life) in the public sector reduces life satisfaction more compared to private sector. These findings are consistent with some previous studies that were done in a similar approach (For Example Karatepe and Bekteshi, 2008; Marks and MacDermid, 1996).

\section{Research Limitations}

This research has some limitations. Data collection through convenience sampling is an important constraint of the research. The study is not longitudinal and the research was conducted only in Ankara and Istanbul, can be stated as another limitation. For this reason, it is suggested that the research needs to be conducted more comprehensively in different time intervals and better to examine the effects sub-sectors of the public and private sectors.

\section{Implications}

It has been determined that the work-life conflict (the effect of the work on personal life) reduces life satisfaction and the sector (public and private) has a moderating role on the relationship between work-life balance and life satisfaction. In the public sector, the work-life conflict (the impact of the work on personal life) is more likely to reduce life satisfaction. On the other hand, the life-work conflict (the effect of personal life on work) does not affect life satisfaction. In this content, the impact of the work on personal life will effect the person himself, his family and social relations. An employee who is not happy in his private life will not be happy at work, and therefore will not be satisfied with his job. Employees who are not satisfied with their job will start to exhibit behaviours that are not desired by the organization. Therefore, it is necessary to provide opportunities to meet the individual needs of people in their private life. In addition to the high performance of happy employees, their commitment to the organization will also increase.

\section{Originality}

In today's high-tec world, there is an increasing number of conscious employees who have a high level of awareness and seek to be more satisfied with life compared to the past employees. In this regard, people's desire to be satisfied with life has also increased. Thus, the expectations of individuals not only from work life but also from private life have increased. This situation has made the work-life balance important for both blue and white collar employees regardless of their sector. That's why, investigating the relationship between worklife balance and life satisfaction and the role of the sector as a mediator on this relationship emerges as an important topic to understand and precisely manage today's employees.

Araştırmacı Katkısı: Mustafa BEKMEZCİ (\%40), İbrahim Sani MERT (\%30), Mohammad ABUBAKAR (\%30). 